This is an original accepted manuscript of an article published by Taylor \& Francis in Studies in

Chinese Religions (2020): https://doi.org/10.1080/23729988.2020.1763676

\title{
Fazang's theory of Zhenru 真如 (Skt. Tathatā) and Zhongxing 種姓 (Skt. Gotra): With a focus on the influence of the Ratnagotravibhāga
}

\section{Zijie LI (SOAS, University of London; rblslzj@hotmail.com)}

Abstract: Fazang 法藏 (643-712) greatly valued the Jiujing yisheng baoxing lun 究竟 一乘寶性論 [Skt. Ratnagotravibhāga; Treatise of the Jewel-nature of Ultimate One] and the Pusa dichi jing 菩薩地持經 [Sūtra of Stages of Bodhisattvas]. These two scriptures played a very significant role in Fazang's theory of tathat $\bar{a}$ 真如, especially his theory of Huayan xingqi 華嚴性起 (Arising of nature on Huayan). Similarly, Fazang's theory of zhongxing 種姓 (Skt. gotra) used the Jiujing yisheng baoxing lun and the Pusa dichi jing as its foundation. Clearly, the Jiujing yisheng baoxing lun is one of the most important scriptures for understanding Fazang's thought. As is widely known, Fazang is one of the most significant figures when discussing the origin and history of rulai zang yuanqi 如來 藏緣起 (dependent arising of Buddha essence) and zhenru yuanqi 真如緣起 (dependent arising of thusness) in Chinese Buddhist history. Therefore, Fazang's quotations and explanations of the Jiujing yicheng baoxing lun are a necessary step towards the resolution of this difficult problem.

The Sanskrit text of the Jiujing yicheng baoxing lun states that there is light of tathāgata (Rulai 如來; One Who Has Thus Come) in the bodies of beings including Mithyātva, which is a quote of the Zhi guangming zhuangyan jing 智光明莊嚴經 [Skt. Sarvabuddhavișayāvatārajñānālokālaṃkāra; Sūtra of Decorating Wisdom and Light]. In contrast, the classical Chinese translation clearly states that this is the quote of the $D a$ Fangguang fo huayan jing 大方廣佛華嚴經 [Skt. Avatamsaka sutra; Flower Garland Sūtra]. Fazang supported the standpoint of the classical Chinese translation of the Ratnagotravibhāga to demonstrate that the Avatamsaka sütra is the real resource and foundation of the xingqi 性起 (arising of nature) theory of his thoughts on Huayan 華嚴.

Keywords: Fazang; Ratnagotravibhāga; zhenru (Skt. tathatā); zhongxing (Skt. gotra); xingqi (arising of nature)

The thought of Huayan (Jp. Kengon) 華嚴 is one of the most significant portions 
of Chinese Buddhism of the Sui and Tang dynasties. Similar to Chan (Jp. Zen) 禪 Buddhism, Huayan Buddhism was also based on although independent from the Dilun 地 論 tradition. Daijō Tokiwa 常盤大定 assumes a stream from the Dilun tradition to Huayan Buddhism and Sanjiejiao 三階教 (Cult of Three Stages). ${ }^{1}$ It is clear that Fazang 法藏 (643-712), as the third founder of Huayan Buddhism was tremendously influenced by his teachers Zhiyan 智儼 (602-668) and Huiyuan 慧遠 (523-592) of the Jingying temple 浄影寺. Huiyuan was one of representatives of the Southern branch of the Dilun tradition, Zhiyan was also familiar with the doctrines of the Dilun tradition and the Shelun 攝論 tradition. Zhiyan is considered one scholar of the Shelun tradition. ${ }^{2}$

Jitsugen Kobayashi 小林実玄 presented the Fazang manuscripts and combines them with contemporary historical manuscripts arranging them chronologically in his paper 'Kegon hōzō no jiden nitsuite' 華嚴法藏の事伝について [On the biography of Fazang]. ${ }^{3}$ Later, Yoshihide Yoshizu 吉津宜英 investigated the finishing date and the order of Fazang's articles in his paper 'Hozo den no saikentō' 法藏伝の再検討 [Reinvestigation on Fazang's biography]. ${ }^{4}$ This prior research indicates that Fazang met Zhiyan in A.D. 662 and became his disciple after that. ${ }^{5}$ Ryōshū Takamine 高峯了州 pointed out that Fazang studied as Zhiyan's disciple from the 20s to 26s, just the last five years of Zhiyan's life. ${ }^{6}$ We can assume that Fazang researched the Dilun and Shelun doctrines deeply during this period. Thus, it is very likely that Fazang utilized the Dilun doctrines in order to structure his Huayan teachings.

In previous discussions of the Buddhist scriptures that influenced Fazang, attention was paid to several classical Chinese translations, such as the Huayan jing 華嚴 經 [Flower Garland Sūtra], the Fahua jing 法華經 [Lotus Sūtra], the Shidi jing lun 十 地經論 [Commentary of the Sūtra of Ten Stages], the Lengqie jing 楞伽經 [Sūtra of Lanka], and the Dacheng qixin lun 大乘起信論 [Awakening of Faith in the Mahayāna]. In this paper, I want to focus on the Jiujing yisheng baoxing lun 究竟一乘寶性論 [Skt.

\footnotetext{
Research conducted for this article was sponsored by a research grant awarded by the Robert H. N. Ho Family Foundation, for a research fellowship of Robert H. N. Ho Family Foundation Postdoctoral Fellow in the SOAS at University of London.

${ }^{1}$ Tokiwa, 'Reiyū,' 182.

${ }^{2}$ Regarding the relationship between Zhiyan 智㒤 and the Shelun 攝論 school, see Ōtake, 'Chigo.'

${ }^{3}$ Kobayashi, 'Hōzō no jiden.'

${ }^{4}$ Yoshizu, 'Hōzō den.'

${ }^{5}$ We can see Chengguan 澄觀 (738-839), Dafangguangfo huayanjing suishu yanyi chao 大方廣佛華嚴 經随疏演義鈔 [Commentary of Da fangguang fo huayan jing], Choe Chiwon 崔致遠 (857-904?), Dang daecheonboksa gosaju beongyeong daedeok beopjang hwasang jeon (Chin. Tang dajianfusi gusizhu fanjing dade Fazang heshang zhuan) 唐大薦福寺故寺主翻經大德法藏和尚伝 [the biography of Fazang at Da Jianfu temple] and Gyōnen (1240-1321), Gokyōshō tsūroki 五教章通路記 [the explanation on Chapter of five kinds of teaching].

6 Takamine, Kegon, 210.
} 
Ratnagotravibhäga; Treatise of the Jewel-nature of Ultimate One] and the Pusa dichi jing 菩薩地持經 [Sūtra of Stages of Bodhisattvas]. In other words, my purpose is to reassess the influence on Fazang and the position in his thought of the Jiujing yisheng baoxing lun and the Pusa dichi jing, which have been neglected by scholars of East Asian Buddhist Studies for a long time. This investigation is a preparatory study ahead of further research into the position of the Jiujing yisheng baoxing lun and the Pusa dichi jing Chinese Buddhism from the Northern and Southern Dynasties to the Tang dynasty. ${ }^{7}$

Although there is some prior research on the relationship between Fazang and the social and political situation of the Tang dynasty, due to my limited knowledge, I will only discuss the problems with Fazang's thought in this paper. ${ }^{8}$

\section{Fazang's theory of Zhenru 真如 (Skt. Tathatā) and Zhongxing 種姓 (Skt. Gotra)}

Fazang established his theory of panjiao (Jp. Kyōhan) 判教 [doctrinal classification] in the Huayan wujiao zhang 華嚴五教章 [i.e. the Huayan yisheng jiaoyi fenqi zhang 華嚴一乘教義分斉章; The Chapter on One Vehicle Teaching of Huayan]. ${ }^{9}$ Among them, the positions of zhongjiao 終教 (final teaching) and dunjiao 頓教 (sudden teaching) are very significant for his system of panjiao. In regard to Fazang's interpretation of zhongjiao and dunjiao, his explanations of zhenru 真如 (Skt. tathatā) and zhongxing 種姓 (Skt. gotra) [caste] are the most important. It is interesting that Fazang, who utilized the Jiujing yisheng baoxing lun and the Pusa dichi jing, emphasized the independence of zhongjiao and dunjiao when explaining zhenru and zhongxing. In particular, this explanation asserted that both zhenru and zhongxing could act as conditional dharmas (youwei fa 有爲法). This problem is related to the foundation of Fazang's panjiao, I will therefore discuss this by concentrating on the Huayan wujiao zhang in this section.

Fazang points out the following in the Huayan jing tanxuan ji 華嚴經探玄記 [Record of the Search for the Profundities of the Huayan Sutra]:

The forth is the gate of xingde 性徳 (nature and virtue). That is, arising refers to the dependent origination of the noumenal principle (lixing 理性) because the noumenal

\footnotetext{
7 About this problem, see Li, 'Kukyō ichijō hōshōron no shinnyosetsu no ichikōsatsu'; idem, 'Nanbokuchō zuitō bukkyō to bosatsujiji kyō.'

8 About the relationship between Buddhism of Tang dynasty and Wu Zhou 武周 period (655-705), see Kamada, Kegon shisōshi, chapter 3; Ishii, 'Daitōa kyōeiken no gōrika to Kegon tetsugaku'; Forte (ed.), Tang China and Beyond; Forte, A Jewel in Indra's Net; Chen, Philosopher, Practitioner, Politician. 9 About prior research on the Huayan wujiao zhang, see Yutsugi, Kegon gokyōshō kōgi; Yoshizu, 'Kegon gokyō shō'.
} 
principle is active in nature (xingxing 行性). The difference between this gate and the prior gate is that the prior one only takes the principle ( $l i$ 理) seriously; however, this gate asserts that both principle and activeness (xing 行) are taken seriously. As is widely known, principle is unconditional and activeness is conditional. The appearance of principle is dharmakāya (fashen 法身), and the perfection of activeness is sambhogakāya (baoshen 報身; reward body). They are different from each other. Why is the noumenal principle active in nature? One answer is because there are a great number of merits and benefits like grains of sand in the rulai zang (Skt. tathägatagarbha). The Dasheng qixin lun states that the meaning of great wisdom (da zhihui guangming 大智慧光明) and the meaning of bianzhao fajie 遍 照法界 [entirely lightening world] is 'non-empty zhenru 真如 (Skt. tathatā) [nonempty thusness]' (bukong zhenru 不空真如). The Mahāparinirvāṇa-sūtra ( $D a$ boniepan jing 大般涅槃經) states that Buddha-nature (foxing 佛性) is the first emptiness, which is called wisdom. That is, there is conditional merit and benefit in unconditional nature. This is the same as the meaning of mozhong xiang 模中像 [the feature reflected in a model] in the Rulaizang jing 如來藏經 [Skt. Tathāgatagarbha-sūtra; Sūtra of Buddha essence] and zhenru wei zhongxing 真如爲 種性 (thusness being zhongxing) in the Jiujing yisheng baoxing lun. Thus, the achievement of the chengwei 成位 [the stage of achievement] is called "nature of fruit' (guoxing 果性). The movement of the nature of fruits is called 'arising of nature'. 四性徳門者、以理性即行性、是故起唯理性起。此与前門何別者? 前 約以理奪行說、今約理本具行說。問、理是無爲、行是有爲。理顯爲法身、行 滿爲報身。法報不同、爲無爲異。云何理性即行耶。答、以如來藏中具足恒沙 性功徳故。《起信論》中、不空真如有大智慧光明義、遍照法界義等。《涅槃》 云、佛性者、名第一義空。第一義空名爲智慧。解云、此即無爲性中具有有爲 功徳法故。《如來藏經》模中像等及《寶性論》真如爲種性等、皆是此義。是故 藉修引至成位、名爲果性。果性赴感、名爲性起。10

Therefore, the noumenal principle is active in nature because as one type of unconditional dharma (wuwei fa 無爲法) it contains an active nature, which is conditional, meaning that both the noumenal principle and active nature act and move like conditional dharmas. To demonstrate this theory, Fazang utilizes not only the Dasheng qixin lun but also the Jiujing yisheng baoxing lun. In addition, we should not ignore that Fazang states: 'There are conditional merits and benefits in unconditional nature. This is the same as the meaning of zhenru wei zhongxing in the Jiujing yisheng baoxing lun.' That is, the sentence

${ }^{10}$ Huayan jing tanxuan ji, $T$ no.1733, 35: 16.405b7-405b18. 
in the Jiujing yisheng baoxing lun is highly significant for understanding Fazang's interpretation, which considers the noumenal principle to act and move as a conditional dharma.

The problem is whether or not we can find the sentence zhenru wei zhongxing 真 如爲種性 in the classical Chinese translation of the Ratnagotravibhāga. Unfortunately, there is neither 'zhenru wei zhongxing 真如爲種性' nor 'zhongxing 種性 (or 種姓)' in this text. Regarding this point, the Sanskrit original text of the Ratnagotravibhāga states:

Therefore, tathāgatagarbha does not remove dharmakāya. Tathāgatagarbha makes selected gotra as svabhāva [nature] as a foundation that cannot be removed from tathatā. Tathāgatagarbha will always be in the being's world and is based on the nature of dharma. ${ }^{11}$ sa khalv eșa tathāgatagarbho dharmakāyāvipralambhas tathatāsaṃbhinnalakṣaṇo niyatagotrasvabhāvaḥ sarvadā ca sarvatra ca niravaśeșayogena sattvadhātāv iti drașțavyaṃ dharmatāṃ pramāṇīkṛtya. （RG, 73) 12

What does this mean? Rulai zang 如來藏 (Skt. Tathāgatagarbha; Buddha essence) is based on the dharmakayya of tathagata and is not different from zhenru. This tathagatagarbha makes the selected foxing 佛性 (Buddha nature) a foundation. It exists in all beings at any time. We know this through the features of dharma. 此明 何義? 明如來藏究竟如來法身、不差別真如体相、畢竟定佛性体。於一切時一 切衆生身中皆無餘盡應知。此云何知、依法相知。1 13

Clearly, the relationship between tathata and gotra is discussed in the Sanskrit original text of the Ratnagotravibhāga, but is not visible in the classical Chinese translation. Thus, it is very likely that Fazang consulted not only the Sanskrit original text of the Ratnagotravibhāga, but the classical Chinese translation as well. As we have seen, Fazang stated that the noumenal principle is active in nature because it is one type of unconditional dharma and contains an active nature, which is conditional, so that both the noumenal principle and active nature act and move like conditional dharmas. This explanation is clearly the same as that of the classical Chinese translation of the Ratnagotravibhāga.

Fazang provided a detailed demonstration of this point in the Huayan wujiao

\footnotetext{
11 Regarding this point, I refer to the modern Japanese translation by Matsumoto, Bukkyō shisō ron, 88.

12 Johnston (ed.), Ratnagotravibhāga.

13 Jiujing yisheng baoxing lun, T no.1611, 31: 3.839b6-839b9.
} 
zhang as stated below.

As is widely known, zhongxing is a conditional dharma but why does this teaching state that tathata $\overline{\text { is }}$ gotra? One answer is that when tathat $\bar{a}$ arises and is combined with delusion, they become basic consciousness (benshi 本識). This means that there is benjue (Jp. hongaku) 本覚 [original enlightenment] in the truth, and undefiled (wulou 無漏) dharma is the reason for return by impression (xunxi 熏習). One could attain gotra through this method. The She dasheng lun 攝大乘論 [Compendium of the Great Vehicle] which was translated in the Liang 梁 period states this is jiexing 解性 [essence nature], and is the benjue asserted in the Dasheng qixin lun. In this scripture, rulai zang contains undefiled dharmas, and is the reason for pure dharmas. Furthermore, the 'ji bi zhenru xing 及彼真如性 [and that thusness]', which is visible in the Jiujing yisheng baoxing lun, as is stated in the Liugen ju jing 六根聚經 [Sūtra of Six Roots], means that the six roots (liugen 六 根) without beginning are based on the bodies of dharma. The reason is that although tathatā is related to all beings, insentient things (feiqing 非情) are not an object in this case. Thus, the principle of tathata $\bar{a}$ is considered the gotra of nature (xing zhongxing 性種性). The relative explanation of the Yuqieshi di lun 瑜伽師地論 (Skt. Yogācārabhūmi-śāstra) [Treatise on the Foundation for Yoga Practitioners] is the same. However, this is the explanation from the standpoint of Shijiao 始教 (initial teaching). It explains zhongxing from the standpoint of shi 事 (phenomena). Therefore, the Pusa dichi jing states that the rough features of zhongxing have been described. In the Jiujing yisheng baoxing lun, the standpoint is zhongjiao. The zhongxing of nature is explained from the standpoint of zhenru. The Foxing lun 佛 性論 [Treatise on Buddha nature] therefore states that zixing qingjing xin 自性清浄 心 (pure heart) is the truth of the path. The Da boniepan jing states that foxing is the first emptiness and wisdom. This takes the standpoint of benjue xing zhi 本覚性智 (the wisdom of original enlightenment), and is based on zhenru. The She dasheng lun states that duowen xunxi 多聞熏習 (influence based on listening) streams from the purest realm of dharma 法界 (Skt. dharma-dhātu). The Dasheng qixin lun considers the body ( $t i$ 体) and features (xiang 相) of zhenru is the reason for internal impression and considers the function (yong 用) of zhenru as the arising of external impression. Through this, they are combined with delusion. Therefore, impression is inside and outside of three parts, namely body, feature, and function (sanda 三大). The function of impression becomes non-dual and there is only one zhenru when delusions are extinguished. The third one is that there is no difference between nature (xing 性) 
and habit ( $x i$ 習) because zhenru has removed features from the standpoint of dunjiao. This is called zhongxing. 問、夫論種性、必是有爲。如何此教約真如爲 種性耶。答、以真如隨緣、与染和合成本識時、即彼真中有本覚、無漏内熏衆 生、爲返流因。得爲有種性。梁《攝論》說爲黎耶中解性。《起信論》中說黎耶 二義中本覚是也。又彼論中如來藏具足無漏、常熏衆生爲浄法因。又《寶性論》 云、及彼真如性者、彼本云如《六根聚經》說、六根如是從無始來、究竟諸法 爲体故。解云、以真如通一切法、今揀去非情故。故約六處衆生数中、取彼畢 竟真如理、以爲性種性也。此与《瑜伽》所說名同。但彼約始教、以理從事正 相而說故。約事中明種性故也。《地持》云、種性庇相我已略說、此之謂也。 《寶性論》中約此終教、以事從理深細而說故、就真如明性種性。是故《佛性 論》云、自性清浄心名爲道諦。又《涅槃經》云、佛性者名第一義空、第一義 空名爲智慧。此等並就本覚性智說爲性種、其習種亦從真如所成故。《攝論》 云、多聞熏習從最清浄法界所流等。又《起信論》中以真如体相二大爲内熏因、 真如用大爲外熏緣、以与無明染法合故。是故三大内外說熏、以熏力故、無明 盡時冥合不二。唯一真如也。三約頓教明者、唯一真如離言說相、名爲種性。 而亦不分性習之異。14

According to this passage, Fazang considered zhongxing a conditional dharma from the initial stage, and this is the background of Fazang's thought. ${ }^{15}$ To equate conditional zhongxing with zhenru, Fazang utilizes the theory of arising zhenru. Zhenru arises and is combined with delusion. They then become basic consciousness and act as conditional dharmas. This active zhenru is related to all dharmas and is the foundation of the existence of the natural caste (xing zhongxing 性種性) and the habit caste (xi zhongxing 習種性). Through this interpretation, zhongxing becomes a conditional dharma, and the rationality of conditional zhenru has been admitted. This is very important for understanding Fazang's theory of zhenru and zhongxing. We should not ignore the fact that the terms Fazang quotes when he explains zhongxing are not benxingzhu zhongxing 本性住種姓 [natural caste] and xisuocheng zhongxing 習所成種姓 [habit caste], which we find in the Yuqieshi di lun translated by Xuanzang 玄牀 (602-664), but xing zhongxing and $x i$ zhongxing, which are the classical Chinese translations in the Pusa dichi jing translated by Dharmakșema (Tanwuchen 曇無䜟; 385-433). Therefore, it is clear that Fazang did utilize the Pusa dichi jing even after the classical Chinese translation of the Yuqieshi di

${ }^{14}$ Huayan yisheng jiaoyi fenqi zhang, $T$ no. 1866, 45: 2.487b29-487c26.

${ }^{15}$ Kim Songchol 金成哲 ('Shushō mui ron no kigen ni kansuru ichikōsatsu') regards the gotra 種姓 of East Asian Buddhism, concluding the case of Fazang, as unconditional dharma. That is to say, there was always a tradition regarding zhongxing (Skt. gotra) as unconditional dharma in East Asian Buddhism. However, I couldn't agree to Kim. This interpretation of Fazang quoted above is also one example. 
lun. ${ }^{16}$

However, with reference to the quote by Fazang above, in the Sanskrit text of the Ratnagotravibhāga, it is written:

The Śrimālā-sūtra states: 'Buddha, tathāgatagarbha is non-emptiness. It surpasses the sands of gaing $\bar{a}$, and is not independent from wisdom. Regarding the integrity of Buddha, it is non-emptiness.' The gotra, namely the principle, is incomprehensible. On this point, the Yogācārabhūmi-śāstra states: 'The six special roots comes without beginning, and are based on the principle of dharma.' aśūnyo bhagavaṃs tathāgatagarbho gan̉gānadīvālukāvyativṛttair avinirbhāgair amuktajñair acintyair buddhadharmair iti / tadgotrasya prakṛter acintyaprakārasamudāgamārthaḥ / yam adhikṛtyoktam / șạ̣āyatanaviśeșaḥ sa tādṛśạ̣ paramparāgato 'nādikāliko dharmatāpratilabdha iti / (RG, 55)

The Shengman jing 勝䡬經 (Skt. Śrīmālā-sūtra) [Lion’s Roar of Queen Śrīmālā] states: 'Buddha, non-empty rulai zang surpasses the sands and is not independent from incomprehensible Buddha dharma.' Regarding the sentence 'ji bi zhenru xing 及彼真如性', as the Liugenju jing stated: 'Buddha, the six roots come without beginning and are based on the principle of dharma.' Regarding the 'fati bu xuwang 法体不虛妄 [the body of dharma is not fake]', as this scripture stated: 'Buddha, the first principle is not false, but nirvāna. The reason is that nature is always eternal and does not change.’ 《聖者勝䯭経》言、世尊、不空如來藏、過於恒沙不離不脱不 思議佛法故。及彼真如性者、依此義故、《六根聚經》言、世尊、六根如是、從 無始來、畢竟究竟諸法体故。法体不虛妄者、依此義故、經中說言、世尊、又 第一義諦者、謂不虛妄涅槃是也。何以故。世尊、彼性本際來常、以法体不變 故。17

Clearly, the classical Chinese translation of the Ratnagotravibhāga, as seen in Fazang's quote, utilizes 'ji bi zhenru xing'及彼真如性. On the other hand, the Sanskrit text states: 'tadgotrasya prakṛter acintyaprakārasamudāgamārthaḥ.' The term 'tathatā' is not visible. In addition, although the classical Chinese translation states that six roots are born from zhenru xing 真如性 [the nature of thusness], this zhenru xing is related to 'tadgotrasya prakrti' in the Sanskrit text, in which 'dharmatā,' instead of tathatā, produces the six roots.

\footnotetext{
${ }^{16}$ About the relationship between the Pusa dichi jing and the theory of zhongxing of Chinese Buddhism, see Li, '7 seiki izen no chūgoku bukkyō no shushōsetsu nitsuite.'

17 Jiujing yisheng baoxing lun, $T$ no.1611, 31: 3.835b27-835c5.
} 
However, Fazang considered all of them zhenru xing. This fact demonstrates that Fazang utilized not only the Sanskrit text of the Ratnagotravibhàga, but also the classical Chinese translation.

In addition, Fazang utilizes the classical Chinese translation term 'zhenru foxing' 真如佛性 [thusness with Buddha nature] in the Dasheng fajie wuchabie lun shu 大乘法 界無差別論疏 [The Sub-commentary on the Treatise on Non-Distinction in the Great Vehicle Dharma Realm] to demonstrate the theory of xingqi.

The Shengman jing (Skt. Śrīmālā-sūtra) states: 'Buddha, if there is no rulai zang (Skt. tathāgatagarbha), one could not remove misery and happiness, and could not pursue nirvāna, because the six kinds of consciousness and xinfa zhi 心法智 (heart and wisdom) flash at every moment. We could not pursue nirvāna through them. Buddha, there is no priority or dharma without extinguishing in the rulai zang.' In the Jiujing yisheng baoxing lun, this passage is explained as yexing 業性 (nature of deed), which is one kind of ten types of Buddha nature. The Jiujing yisheng baoxing lun states: 'If we explain the Foxing qingjing zhengyin 佛性清净正因 (pure reason of Buddha nature), we will make two kinds of karma among the beings of buding ju 不定聚 (undecided beings). The first one is a dislike of a variety of miseries through recognizing them. The second one produces the heart of pursuing and blessing by recognizing the happiness of niepan xiji 涅槃希寂 (pursuing nirvāna). Furthermore, there are zhenru foxing as a foundation in the beings who have great roots if we take a stand in two kinds of dharma. There would not be this heart without Buddha nature and causes. If not so, the beings who have no nirvāna nature, for instance ichanti 闡提 (Skt. icchantika) [beings who cannot attain the Buddhahood], could establish the heart of Bodhi. When we say wu foxing 無佛性 (lacking Buddha-nature), one has not practiced one vehicle (yisheng 一乘) [summarizing Buddha's teachings as one conclusion] when the nature is still not independent from delusion, one cannot approach teachers or sages.' The “Xingqi” chapter 性起品 of Huayan jing therefore states: 'There is light of rulai zang in the bodies of beings of xieding ju 邪定聚 (deciding beings with evil deeds). It will become the merit and great root of beings in the future. It is always said that icchantika cannot enter nirvāna, one asks what does this mean? One answer is that they want to show the cause of slandering the Mahāyāna. They wish to change the hearts of those slandering the Mahāyanna. There was pure Buddha nature in icchantikas originally, so we cannot say they have no pure nature.' This is the quote from the Huayan jing that makes zhenru the cause of Buddha nature. Thus, there is xing 性 (nature) in all beings. 《勝髶經》云、世尊、 
若無如來藏者、不得厭苦樂、求涅槃。何以故。於此六識及心法智、此七法刹 那不住。不種衆苦、不得厭苦樂、求涅槃。世尊、如來藏者無前際、不起不滅 法。種諸苦、得厭苦樂、求菩提。乃至廣說。《寶性論》中釋此文、当十種佛性 中業性也。彼論云、略說佛性清浄正因、於不定聚衆生、能作二種業。一依見 世間種種苦惱、厭諸苦故。二依見涅槃希寂樂故、生求心・欲心・願心。又云、 此二種法善根衆生、有一切依因真如佛性。非離佛性無因緣故、起如是心。若 無因緣生如是心者、一闡提等無涅槃性、應發菩提心。無佛性者、以性未離一 切客塵煩惱諸垢、於三乘中未曽修習一乘信心。又未親近善知識等、未修習夙 親近善知識因緣。是故《華嚴》「性起」中言、次有乃至邪定聚等衆生身中、皆 有如來日輪光照故、作彼衆生利益、作未來因善根、増長諸白法故。向說一闡 提常不入涅槃性者、此義云何。爲欲示現謗大乘因緣故。此明何義。爲欲回轉 誹謗大乘心、不求大乘心故。依無量時故如是說。以彼實有清浄性故、不得說 彼常畢竟無清浄性。解云、此亦論中自引《華嚴》、成立真如爲佛性起行之因。 是故一切衆生悉有性也。18

According to Fazang's interpretation, the theory of xingqi of Huayan is related to the arising and cause of zhenru foxing in all beings. In addition, he considers the Shengman jing and the Jiujing yisheng baoxing lun the foundations of this theory. We can find this passage of the Shengman jing quoted in the Jiujing yisheng baoxing lun if we examine the relevant portion, but there is no zhenru foxing in the Sanskrit text. We could therefore state that Fazang's theory of xingqi is based on the classical Chinese translation of the Ratnagotravibhāga rather than the Sanskrit text. Fazang regards the classical Chinese term zhenru foxing as one kind of conditional dharma. It is the foundation of the misery and happiness of all beings, and this is called xingqi by Fazang. It is widely known that the theory of xingqi is one of the roots and foundations of Fazang's thought on Huayan. We should recognize the importance of the classical Chinese translation of the Ratnagotravibhāga in this case.

Regarding this point, let us confirm the explanation in the Ratnagotravibhāga. It is written:

'If there is no Buddha nature, there is no dislike of misery either. Furthermore, there is also no pursuing and blessing in nirvāna.' As similar content, the Śrīmālā-sütra states: 'Buddha, if there is no existence of tathägatagarbha, there will be no dislike of a variety of miseries and the pursuit of nirvāna.' It can be summarized that pure

${ }^{18}$ Dasheng fajie wuchabie lun shu, T no.1838, 44: 1.68c7-69a1. 
gotra, which is called Buddha nature (or gotra that can purify Buddha nature ${ }^{19}$, buddhadhātuviśuddhigotra) exists in all beings, including xieding ju, and causes two kinds of conclusions. ...... 'Regarding transmigration and nirvāna, their existence is due to the existence of gotra. There is no being who does not have gotra.' Transmigration whereby one can see misery and mistakes, and nirvāṇa whereby one can see happiness and merit, exist when there is gotra. They are not unreasonable. buddhadhātuh sacen na syān nirvidduḥkhe 'pi no bhavet / necchā na prārthanā nāpi prāṇidhir nivṛtau bhavet // 40 // tathā coktam / tathāgatagarbhaś ced bhagavan na syān na syād duhkkhe 'pi nirvinna nirvāṇa icchā vā prārthanā vā praniidhirveti / tatra samāsato buddhadhātuviśuddhigotraṃ mithyātvaniyatānām api sattvānāṃ dvividhakāryapratyupasthāpanaṃ bhavati / ...... bhavanirvāṇatadduḥkhasukhadoṣaguṇekṣaṇam / gotre sati bhavaty etad agotrānāạm na vidyate // 41 // yad api tat saṃsāre ca duḥkhadoṣadarśanaṃ bhavati nirvāṇe ca sukhānuśaṃsadarśanam etad api śuklāṃśasya pudgalasya gotre sati bhavati nāhetukaṃ nāpratyayamiti // (RG,35-37)

'If there is no Buddha nature, there is no dislike of misery either. Furthermore, there is also no pursuing or blessing by nirvāna.' Regarding this, the Shengman jing states: 'Buddha, if there is no rulai zang, there is no dislike of misery too. Furthermore, there is also no pursuing and blessing by nirvāna.' What does this mean? It can be summarized that pure Buddha nature exists in all beings, including buding $j u$, and causes two kinds of conclusions (karmas). ..... 'Misery and happiness depend on nature. If there is no Buddha nature, this heart will not exist.' What does this mean? Transmigration whereby one can see misery and mistakes, and nirvāna whereby one can see happiness and merit, will exist when there is zhenru foxing, which exists in beings with great roots. This kind of heart will not arise if there is no Buddha nature and causes. 若無佛性者、不得厭諸苦、不求涅槃樂、亦不欲不願。以是義故、 《聖者勝䯱經》言、世尊、若無如來藏者、不得厭苦樂求涅槃、亦無欲涅槃、 亦不願求、如是等此明何義? 略說佛性清浄正因於不定聚衆生能作二種業。 ……見苦果樂果、此依性而有、若無佛性者、不起如是心。此偈明何義。凡所 有見世間苦果者、凡所有見涅槃樂果者、此二種法、善根衆生有一切依因真如 佛性。非離佛性無因緣故起如是心。20

19 Matsumoto, Bukkyō shisō ron, Chapt. 4.

20 Jiujing yisheng baoxing lun, T no.1611, 31: 3.831a7-831a26. 
In the Sanskrit text, the term 'buddhadhātuviśuddhigotra,' which contains both 'gotra' and 'buddhadhātu', is used. From this perspective, we can recognize the misunderstanding in the understanding of the classical Chinese translation of the Ratnagotravibhāga (Ch. Jiujing yisheng baoxing lun) which asserts 'zhongxing 種姓 $($ Skt. gotra $)=$ foxing 佛性 (Skt. buddhadhātu)'. The classical Chinese translation translated both of these terms as 'buddha nature' (foxing 佛性) and ignored the difference between the two terms. Namely, instead of gotra, zhenru foxing became the reason and resource. On the other hand, in the Sanskrit text of the Ratnagotravibhagga, buddhadhātuviśuddhigotra exists in whole beings and leads to two kinds of conclusions. Nirvāna only exists in beings who have gotra. This differs from the classical Chinese translation, in which zhenru foxing is in all beings and can lead to a variety of conclusions (karmas). Clearly, Fazang's explanation was based on the classical Chinese translation of the Jiujing yisheng baoxing lun.

Next, concerning the theory of zhongxing, I will examine Fazang's interpretation. In the Huayan wujiao zhang, it is written:

The Yuqieshi di lun states: 'There are two kinds of zhongxing, one is benxing zhu zhongxing [principal caste], the other one is xisuocheng zhongxing [habit caste]. Benxingzhu zhongxing is the greatness of the six places of the Bodhisattvas. They arise without beginning, and contain their original features. Xisuocheng zhongxing is attained by the great roots, which come from long practicing.' The benxing [principal nature] means the greatness of yichu 意處 (consciousness) of the six places, namely considering the benjue jiexing 本覚解性 (original enlightenment and its essential nature), xing zhongxing. The She dasheng lun, which was translated during the Liang dynasty therefore stated that wen xunxi 聞熏習 (influence of listening) could combine with jiexing to become the cause of all sages. However, the Yuqieshi di lun stated that only beings who possess zhongxing can decide to practice. We should therefore know that it is possible to combine principal zhongxing and habit zhongxing into one zhongxing. For this reason, these two kinds of arising are the one and only way. In addition, we should also not arrange them. On the other hand, when one has achieved the kanren 堪任 (patience) stage there are principal zhongxing and habit zhongxing. There are two meanings, but not two objects. As the She dasheng lun stated, the two meanings combine into one reason. One can ask if there is any difference between these two kinds of zhongxing and the two kinds of zhongxing that are asserted in the Renwang jing 仁王經 [Sūtra of Benevolent King] and the Pusa 
yingluo benye jing 菩薩瓔珞本業經 [Sutra of the Diadem of the Primary Activities of the Bodhisattvas]? One answer is that those scriptures are based on the standpoint of position (wei 位). Firstly, one practices at the stage of xi zhongxing. After that, he could enter the higher stage named xing zhongxing. Xi zhongxing is in the shizhu十 住 (ten stages of the development), xing zhongxing is in the shixing 十行 (ten stages of the transcendence). It is called shanqu 善趣 (great paths) before the three types of greatness (sanxian 三賢), instead of zhongxing. The Yuqieshi di lun considers original existence principal zhongxing. There is no arrangement between the two kinds of zhongxing. Thus, the canons state ' $x$ i gu cheng xing' 習故成性 (deriving from habit), and treatises state 'yi xing qi xi' 依性起習 [attain habit from nature]. which combine with each other. Canons and treatises unite into the complete truth and teaching. One may ask if the canons state that zhongxing comes after deciding to practice, and if the treatises state zhongxing arises before that. How should we understand this? One answer is that because the function and effect will appear after achieving the zhide 至得 (ultimate achievement) stage, the canons state there is dependence on the function and effect after achieving the three types of greatness stage. Therefore, the assertion that states the function and effect would appear before that stage is the content of treatises. There is no contradiction between the canons and treatises on this point. Either of them could become the cause of the other one. One can ask again, how could we know the course from zhongxing to the kanren stage? One may answer that both principle and habit are indispensable if we discuss zhongxing. 《瑜伽論》云、種性略有二種。一本性住、二習所成。本性住者、 謂諸菩薩六處殊勝。有如是相、從無始世展轉伝來、法爾所得。習所成者、謂 先串習善根所得。此中本性即内六處中意處爲殊勝、即攝頼耶識中本覚解性、 爲性種性。故梁《攝論》云、聞熏習与阿頼耶識中解性和合、一切聖人以此爲 因。然《瑜伽》既云具種性者方能發心、即知具性習二法成一種性。是故此二 緣起不二、隋關一不成。亦不可說性爲先、習爲後。但可位至堪任已去、方可 約本說有性種、約修說爲習種。然有二義而無二事。如上《攝論》云、二義和 合爲一因、故得知也。問、此二種性与《仁王》及《本業經》中六種性内習種 性種有何差別耶。答、彼經大都約位而說。以初習爲習種性、久習積成爲性種 性故。說習種在十住、性種在十行。三賢之前但名善趣、不名種性。《瑜伽》中 久習名習種、約本爲性種。而此二種非初非中後。是故經說習故成性、論中說 爲依性起習。良以此二互成緣起、無二相故。經論互說、義方備足。又經說種 性在發心後、論中種性在發心前。何以爾者。以其至得位時功能方顯。是故經 說在三賢位中。然彼功能必有所依、是故論中說在位前。要由功能顯、方可說 有故。經不違論、要由有性方起功能故。論不違經、亦是互舉、義意融通。問、 
又以何義知種性至堪任位耶。答、以論說種性、必具性習。21

We should notice that Fazang utilizes not only the 'benxing zhu zhongxing 本性住種姓, xi suocheng zhongxing 習所成種姓' used in the Yuqieshi di lun, but also the 'xing zhongxing 性種性, xi zhongxing 習種性' used in the Pusa dichi jing, and asserts 'benjue 本覚 = jiexing 解性 = benxing zhu zhongxing 本性住種姓 =xing zhongxing 性種性.' He combines benxing zhu zhongxing with xi suocheng zhongxing, and considers them one zhongxing. Through this assertion, Fazang combined and confused the new classical Chinese translations of Xuanzang with old translations, such as the Pusa dichi jing and the Pusa yingluo benye jing, and integrated all of them.

The resources of the terms 'xi zhongxing 習種性, xing zhongxing 性種性,' which are utilized in the Renwang jing, are in the Pusa dichi jing. The Pusa yingluo benye jing makes use of them and asserts a group of concepts 'xi zhongxing 習種性, xing zhongxing 性種性, dao zhongxing 道種性 (path caste), sheng zhongxing 聖種性 (saint caste), dengjue xing 等覚性 (equal enlightenment), miaojue xing 妙覚性 (ultimate enlightenment).' Therefore, at least from the standpoint of the theory of zhongxing, the purpose of the Pusa yingluo benye jing is to develop the theory of zhongxing, that began in the Pusa dichi jing and was transformed at the stage of the Renwang jing. That is to say, xi zhongxing is a relatively low stage. We can see the following explanation of this assertion in the Pusa yingluo benye jing.

It is impossible that all Buddhas and Bodhisattvas attain the fruit of xiansheng 賢聖 (Sageliness and worthiness) without undergoing the ten gates of precepts. The first zhuxiang 住相 [feature of stableness] is the first xi zhongxing. In this way, the other nine people can practise and achieve the stages of jiuzhu 九住 (nigh types of stableness), shixing 十行 (ten types of transcendence), shi huixiang 十回向 (ten types of reward), shidi 十地(ten stages of development), wugou di 無垢地(the pure stage).' The incomprehensible deed will also become larger and larger. 若一切佛 • 一切菩薩、不由此十戒法門得賢聖果者、無有是處。是初住相習種性中第一人、 如是下九人法行漸漸増廣、乃至九住 $\cdot$ 十行 $\cdot$ 十回向 $\cdot$ 十地 無垢地、亦漸増 廣不可思議行。 22

That is, xi zhongxing is the first stage of the first zhuxiang. After that, there are other stages such as jiuzhu, shixing, shi huixiang, shidi, wugou di. In other words, xi zhongxing

21 Huayan yisheng jiaoyi fenqi zhang, T no.1866, 45: 2.485c14-486a14.

${ }^{22}$ Pusa yingluo benye jing, T no.1485, 24: 2.1012b10-1012b14. 
is the lowest stage of beings' practice. One could enhance his practice stage after that and enter the xing zhongxing. This kind of explanation differs from the theory of zhongxing in the Pusa dichi jing and the Yuqieshi di lun. However, Fazang integrated them.

As is widely known, icchantika become the central issue when we discuss the theory of zhongxing. Concerning this point, in the Huayan wujiao zhang Fazang stated as below.

One asked, if there is nature (xing 性) in all beings, why do they assert the existence of beings without nature? Another one answered, regarding this, there is explanation in the original treatises. The Jiujing yisheng baoxing lun therefore states: 'It is said that there is no nirvāna nature in icchantika, so they cannot enter nirvāna. How should we understand this? Another one answered, because they want to show the reason for slandering Mahāyāna Buddhism. That is to say, they said this infinite times to change the heart of this slandering Mahāyāna Buddhism. We should therefore recognize that there is pure Buddha nature in icchantika originally. 問、若並有性、 如何建立五種性中無性者耶。答、論自有釋。故《寶性論》云、一向說闡提無 涅槃性不入涅槃者、此義云何。爲欲示顯謗大乘因故。此明何義。爲欲回轉誹 謗大乘心。依無量時故作是說。以彼實有清浄佛性故。23

Clearly, Fazang still utilized the Jiujing yisheng baoxing lun to demonstrate that the assertion that icchantika could not become Buddha was a method used to guide all beings to the path of Mahāyāna Buddhism. Fazang stated that there is no being who could not become a Buddha because all beings, including icchantika, have pure Buddha nature. The evidence for this assertion is the Jiujing yisheng baoxing lun.

The problem is whether or not Fazang's interpretation fits the original Ratnagotravibhāga text. To clear this problem, let us examine the Ratnagotravibhāga statements.

'Regarding transmigration and nirvāna, their existence is owed to the existence of gotra. There is no being without gotra.' Transmigration whereby one can see misery and mistakes, and nirvāna whereby one can see happiness and merit, will exist when there is gotra. They are not unreasonable. If they exist without gotra, the icchantika who belong to the gotra without nirvanna would exist. On the other hand, through four kinds of practice that are close to good knowledge, there would be no development of gotra that could purify delusion. This is impossible. Concerning

${ }^{23}$ Huayan yisheng jiaoyi fenqi zhang, T no.1866, 45: 2.486c8-486c14. 
this, scripture states: 'There is light of the tathägata in the bodies of beings including mithyātva (xieding ju 邪定聚). It will become the merit and great root of beings and magnify great dharmas in the future. ${ }^{24}$ In contrast, it is always said that icchantika cannot enter nirvāna, so what does this mean? The reason is that they want to show the cause of slandering the Mahāyāna. They wish to change the hearts of those slandering the Mahāyāna. This is the sense of another time. There is no impure status due to the existence of viśuddhagotra (pure gotra, alternatively purified nature by gotra). yad api tat samsāre ca duhkhadoṣadarśanaṃ bhavati nirvāṇe ca sukhānuśaṃsadarśanam etad api śuklāṃśasya pudgalasya gotre sati bhavati nāhetukạ̣ nāpratyayam iti / yadi hi tad gotram antareṇa syād ahetukam apratyayaṃ pāpasamucchedayogena tad icchantikānām apy aparinirvāṇagotrāṇāṃ syāt / na ca bhavati tāvadyāvadāgantukamalaviśuddhigotraṃ trayāṇāmanyatamadharmādhimuktị̣ na sa mudānayati satpuruṣasaṃsargādicatuhśuklasamavadhānayogena / yatra hyāha / tatra paścādantaśo mithyātvaniyatasaṃtānānāmapi sattvānāṃ kāyeșu tathāgatasūryamaṇḍalaraśmayo nipatanti anāgatahetusaṃjananatayā saṃvardhayanti ca kuśalairdharmeriti / yatpunaridamuktamicchantiko 'tyantamaparinirvāṇadharmeti tan mahāyānadharmapratigha icchantikatve heturiti mahāyānadharmapratighanivartanārthamuktạ̣ kālāntarābhiprāyeṇa / na khalu kaścitprakṛtiviśuddhagotrasaṃbhavādatyantāviśuddhidharmā bhavitumarhasi / (RG, 36-37)

Misery and happiness depend on nature. If there is no Buddha nature, this heart will not exist.' What does this mean? Transmigration whereby one can perceive misery and mistake, and nirvāna whereby one can perceive happiness and merit, will exist when there is zhenru foxing, which exists in beings with great roots. This kind of heart will not arise if there is no Buddha nature and causes. That is, the Buddhist chant states: 'Seeing misery and happiness is based on nature.' If there could be this heart without causes, the beings who have no ability to enter nirvāna, for instance the icchantika, could establish their hearts of Bodhi. The Buddhist chant states that if there is no Buddha nature, this heart could not arise. That is to say that one who has not practiced one vehicle when the nature is still not independent from delusion, could not approach teachers or sages. The 'Xingqi' chapter of Huayan jing therefore states: 'There is light of rulai in the bodies of beings of xieding ju. It will become the

${ }^{24}$ Takasaki Jikido 高崎直道 $(H \overline{o s h} \bar{o}$ ron, 64) points out that this portion quoted by the Ratnagotravibhäga is a part of the Zhi guangming zhuangyan jing, not the Da fangguang fo huayan jing. 
merit and great root of beings in the future. One asked, it is always said that icchantika cannot enter the nature of nirvāna, what does this mean? Another one answered, because they want to show the cause of slandering the Mahāyāna. They wish to change the hearts of those slandering the Mahāyāna. There is pure Buddha nature in the icchantikas originally, so we cannot say they have no pure nature.' 凡 所有見世間苦果者、凡所有見涅槃樂果者、此二種法、善根衆生、有一切依因 真如佛性、非離佛性無因緣故起如是心。偈言見苦果樂果、此依性而有故。若 無因緣生如是心者、一闡提等無涅槃性、應發菩提心。偈言若無佛性者、不起 如是心故。以性未離一切客塵煩惱諸垢、於三乘中未曾修習一乘信心。又未親 近善知識等、亦未修習親近善知識因緣。是故《華嚴》「性起」中言、次有乃至 邪見聚等、衆生身中皆有如來日輪光照、作彼衆生利益、作未來因善根、増長 諸白法故。向說一闡提常不入涅槃、無涅槃性者、此義云何。爲欲示現謗大乘 因故。此明何義。爲欲回轉誹謗大乘心、不求大乘心故。依無量時故、如是說。 以彼實有清浄性故、不得說言彼常畢竟無清浄性。25

Clearly, gotra has become the reason why beings dislike the misery of transmigration and pursue the happiness of nirvāna. In the classical Chinese translation of the Ratnagotravibhāga, zhongxing was translated as zhenru foxing and foxing, and xing. In the Sanskrit text, the existence of gotra leads to transmigration whereby one can see misery and mistake, and nirvāna whereby one can see happiness and merit. If there is no gotra, the beings who have no ability for nirvanna, for instance icchantika, could pursue nirvāna. On the contrary, in the classical Chinese translation, due to the existence of zhenru foxing, both misery and happiness exist. In other words, the existence of gotra is the resource for pursuing nirvāna. In addition, according to the classical Chinese translation, if there could be a heart without causes, the beings who have no ability for nirvāna, for instance icchantika, could establish their hearts of Bodhi. The possibility of nirvāna for icchantika becomes ambiguous. This is also a difference from the Sanskrit text. It goes without saying that Fazang's position was close to that of the classical Chinese translation of the Ratnagotravibhāga.

In addition, there is a significant problem. That is, the Sanskrit text of the Ratnagotravibhāga states: 'There is light of tathāgata in the bodies of beings including mithyātva. It will become the merit and great root of beings and magnify great dharmas in the future.' According to Takasaki, this part is the quote of the Zhi guangming zhuangyan jing 智光明莊嚴經 [Skt. Sarvabuddhaviṣayāvatārajñānālokālaṃkāra; Sūtra of Decorating Wisdom and Light]. In contrast, the classical Chinese translation

25 Jiujing yisheng baoxing lun, $T$ no1611, 31: 3.831a26-831b9. 
clearly states that this is the quote of the Da Fangguang fo huayan jing 大方廣佛華嚴 經 [Skt. Avatamsaka sutra; Sūtra of Flower Garland]. It is extremely interesting that Fazang supported the standpoint of the classical Chinese translation of the Ratnagotravibhāga (Chin. Jiujing yisheng baoxing lun) to demonstrate that the Da fangguang fo huayan jing is the real resource and foundation of the xingqi theory of his thoughts on Huayan. However, it is incredible that in the current classical Chinese translation of the Avatamsaka sūtra, we cannot find a portion similar to the quote above. ${ }^{26}$ That is to say, it is highly likely that Fazang mainly utilized the classical Chinese translation of the Ratnagotravibhāga instead of the Sanskrit text, and the classical Chinese translation of the Da fangguang fo huayan jing, to demonstrate his xingqi theory of Huayan. It is extremely important to understand the position of the Jiujing yisheng baoxing lun not only in Fazang's system, but in the whole history of Chinese Buddhist thought.

\section{The background of Fazang's interpretation}

As I have shown above, Fazang utilized the Jiujing yisheng baoxing lun to demonstrate his theories of zhenru and zhongxing. However, we cannot ignore the influence of Zhiyan and Wŏnhyo 元曉 (617-686) on Fazang. I will therefore examine the cases of Zhiyan and Wŏnhyo in this section.

There are several kinds of Zhiyan's writing that had a great influence on Fazang and Korean Buddhism ${ }^{27}$. Among them, the most important one is the Huayan jing neizhangmen deng za kongmu zhang 華嚴經内章門等雜孔目章 [=Huayan kongmu zhang 華嚴孔目章; An Essay on the Outline of Huayan], which was written by Zhiyan during his last years. ${ }^{28}$ The Huayan kongmu zhang not only arranges Zhiyan's thought and a variety of Chinese Buddhist theories in that period, but also introduces the theories of panjiao. ${ }^{29}$ In this section, I will examine the Zhiyan's understanding of zhenru.

In the Huayan kongmu zhang, Zhiyan states:

\footnotetext{
${ }^{26}$ Although we can find the similar case in the classical Chinese translation of the Avatamsaka sütra, its exact expression differs from that of Fazang. Namely, the origin of Fazang's theory of Huayan xingqi 嚴性起 [arising of nature on Huayan], which can be found in the Huayan wujiao zhang and the Dasheng fajie wuchabie lun shu, is more similar with the expression of the classical Chinese translation of the Ratnagotravibhāga, instead of that of the Avatamsaka sütra.

${ }^{27}$ For major studies on Zhiyan, see Kimura, Shoki Chügoku Kegon shisō, Part 2, Chapt. 2.

${ }_{28}$ As a representative of the research to the Huayan jing neizhangmen deng za kongmu zhang, Takamine, Kegon kumoku shō kaisetsu, is significant.

29 About Zhiyan’s panjiao (Jp. kyōhan) 判教, see Nakajō, ‘Chigon no kyōhan,' 612-613.
} 
Wen xunxi streams from zhenru, which is the basis of the three kinds of wisdom that can become seeds. Other dharmas cannot act like zhenru. One asked, as is widely known, zhenru contains morality and streams by itself, but if what you said was correct, how could zhenru receive the impression (xunxi 熏習)? Another one answered, actually, zhenru will not guard its nature, and arises through causes. This course is called impression. 聞熏習從真如流。当知真如是三慧本、受熏成種、 轉得増上。餘法則無。問、若爾、真如具徳、但自流出。何假更熏。答、真如 實不守自性、待緣方起、故說熏也。30

That is to say, although zhenru is the basis, it can receive impressions and arise if some causes exist. In this case, wen xunxi and seeds would be streamed. This is the theory of zhenru yuanqi 真如緣起 [the arising of thusness]. Clearly, this explanation of Zhiyan is very similar to that of Fazang.

It is clear that Zhiyan utilizes the Dasheng qixin lun and the Jiujing yisheng baoxing lun to demonstrate his theory of zhenru.

What is darkness of mind? This means zhenru because zhenru could establish darkness of mind. There will be no darkness of mind if there is no zhenru. Thus, the Dasheng qixin lun states that all kinds of dharma, including darkness of mind, are the hearts of beings and the features of birth and death in zhenru. According to this meaning, one can enter the gate of zhenru through one vehicle. We could manifest its rationality by prior example. According to the Jiujing yisheng baoxing lun, the bodhisattva who has just started his practice will cause three kinds of emptiness mind. The first one is to remove empty Buddha essence (Kong rulai zang 空如來藏), and recognize the falseness of things. It is also called gate of empty freedom (kong jietuo men 空解脱門). After this kind of heart arising, extinguishing will exist and could become nirvāna. This is the first one. The second one is to consider empty existence. Some people could consider all things emptiness. This is the second one. The third one is to cause the thought whereby there is another emptiness removing other kinds of dharma such as formal dharma. In addition, this kind of emptiness could be attained by practice. 無明是何義。是真如義。何以故。真如成無明故。若無真 如、即無無明。故《起信論》從無明等一切諸法、皆是摩訶衍衆生之心、真如 体中生滅相用也。若可此義、即得随順入真如門。一乘所目、亦入一乘。對前 正觀、舉其相似、以明其正。依《寶性論》、新發意菩薩修行心中遂成空亂意、 略有三種。一離空如來藏、以失變壞物修行、名爲空解脱門。起如是心、實有

${ }^{30}$ Huayan jing neizhangmen deng za kongmu zhang, $T$ no.1870, 45: 545a23-545a26. 
物斷滅、後得涅槃。是第一亂意。二者、又復有人以空爲有、物義應得空。是 第二亂意。三者、又生是心、離色等法別更有空、我修行爲得彼空。31

We should notice that Zhiyan utilized both the Dasheng qixin lun and the Jiujing yisheng baoxing lun here. ${ }^{32}$ He firstly used the theory of zhenru of the Dasheng qixin lun to assert that delusion can be generated from zhenru. This is probably the development of the theory of empty zhenru and un-empty zhenru in the Dasheng qixin lun. Furthermore, Zhiyan points out that the Jiujing yisheng baoxing lun is evidence of this theory of zhenru. Clearly, we can detect the relationship and interaction between Zhiyan and Fazang about this point.

Wŏnhyo's influence on Fazang should not be ignored. According to Yoshizu, Wŏnhyo's influence on Fazang not only involves the extent of thought, but also exact sentences and terms. ${ }^{33}$ Finally, I therefore examine Wŏnhyo's quotations and interpretation of the Jiujing yisheng baoxing lun concentrating on his theory of zhongxing.

Wŏnhyo utilized the Jiujing yisheng baoxing lun and stated as follows in the Beophwa jong-yo (Chin. Fahua zongyao) 法華宗要 [Doctrinal Essentials of the Lotus Sutra].

One asked, the body that arises from the causes and conditions of the previous life of an arhat definitely extinguishes. In this case, from which stage could we attain the Buddha path? Another one answered, one will not transmigrate into the three worlds when he has achieved the stage of an arhat and stopped a variety of causes and conditions in the three worlds. Then, pure Buddha nature will appear and remove one from the three worlds. The mental afflictions will disappear. One could attain the Buddha path after listening to the Fahua jing. The third one is that as the Jiujing yisheng baoxing lun states, one asked, how should we understand the assertion that icchantika cannot enter nirvāṇa because there is no ability for nirvāna? Another one answered, this is to change the people who slander the Mahāyāna and make them believe in the Mahāyāna. It will take considerable time, because they have pure nature. Through this passage, we know that the assertion that states the existence of icchantika is merely a temporary expedient, not a true teaching of one vehicle as has been stated. Thus, all beings can attain Buddhahood. This is the true teaching.

31 Huayan jing neizhangmen deng za kongmu zhang, T no.1870, 45: 550b9-550b20.

32 About the relationship between zhenru foxing in the classical Chinese translation of the Ratnagotravibhāga and zhenru in the Dasheng qixin lun, see Li, 'Daijō kishin ron no shinnyosetsu no ichikōsatsu.'

33 Yoshizu, 'Hōzō Daijō kishin ron giki.' 
Moreover, one asked again, how can we explain the later quotation if we agree with the prior one? Another one answered, as stated by all teachers, although the assertions that prevent and persuade buding xing have always been asserted in the teachings of one vehicle, they are a kind of conventional teaching. In other words, this assertion is not the ultimate truth. Both the Jiujing yisheng baoxing lun and the Fahua lun 法 華論 [Treatise on the Lotus Sutra] maintain the later convenient teaching. The existence of an arhat who is born in the pure land of the Da zhidu lun 大智度論 [The Treatise on the Great Prajñāparramitā] is based on the theory of convertible beings. Thus, it does not contradict the truth. One asked, how can we explain the prior quotation if we agree with the later one? Another one answered, as the Jie shenmi jing 解深密經 [Skt. Samdhinirmocana Sūtra; Noble Sūtra of the Explanation of the Profound Secrets] has stated, because there are some beings who cannot attain the boundary of the bodhisattva and Buddhahood, they will enter the wuyu niepan 無餘 涅槃 (nirvāna without reminder). As for them, they are called yixiang quji一向趣 寂 [beings pursuing the extinction] because it is impossible to enter the boundary of extinguishable nirvāna and become a bodhisattva and attain Buddhahood. However, when they want to enter the boundary of extinguishable nirvāna, they have to surpass eighty thousand kalpa (jie 劫) or sixty, forty, twenty thousand kalpa, to cultivate their hearts to enter the Mahāyāna. After that, they can transmigrate into the pure land and maintain the Buddha path. In contrast, convertible beings can enter the Mahāyāna due to remaining in youyu niepan 有餘涅槃 (nirvāna with reminder). This has been stated by the Yuqieshi di lun. The doctrine of abhidharma is not an extreme teaching because it considers one vehicle a convenient teaching. 問、阿羅 漢先世因緣之所受身、必應当滅。住在何處而具足佛道。答、得阿羅漢時、三 界諸漏因緣盡故、更不復生三界。有浄佛立、出於三界、乃至無有煩惱之名。 於是国立佛所聞《法華經》、具足佛道。三者、《寶性論》云、問、說閪提無涅 槃性、常不入涅槃者、此義云何。爲欲示顯謗大乘因故。此明何義。爲欲回轉 誹謗大乘心、不求大乘心。依無量時、故作是說。以彼實有清净性故。依是等 文、当知諸教說有二乘定不成佛、及說無性有情等言、皆是方便不了義說。若 說一乘、更無第二。一切衆生皆当作佛。如是經典是真了義。問、若立初師義 者、後師所引文云何和会。彼師通曰、諸一乘教所說諸文、皆爲護彼不定性者、 皆是方便、故不相違。《法華論》文及《寶性論》亦爲述後方便教意。《智度論》 文說阿羅漢生浄土者、是約不定種性声聞。由是道理、亦不相違。問、若立後 師義者、前所引證云何得通。彼師通云、《深密經》說終不能令当坐道場證得 無上正等菩提者、是明決定当入無餘。永不能令不入無餘、直證無上正等菩提。 是故說爲一向趣寂。然彼声聞入無餘時、住八萬劫或住六萬四萬二萬、然後起 
心、即入大生於浄土、具足佛道。若論不定種性人者、唯住有餘、依地入大。 如《瑜伽論》分明說故、是故彼經亦不相違。對法論文說一乘教爲方便者、是 述三乘權教之意、而非究竟道理之說。 34

As we know, Wŏnhyo definitely quotes the Jie shenmi jing and the Yuqieshi di lun in the Beophwa jong-yo. Both of them were translated by Xuanzang. We can therefore realize that despite knowing of the existence of Xuanzang's translations, Wŏnhyo still utilized the old classical Chinese translations to interpret Xuanzang's translations. In particular, Wŏnhyo used the assertion of the Jiujing yisheng baoxing lun about changing the people who slander the Mahāyāna to make them believe in the Mahāyāna to explain the existence of icchantika, who it is said cannot enter nirvāna. That is to say, the opinion that some beings cannot enter nirvāna is not an extreme teaching. All these assertions are only convenient teachings. Clearly, Wŏnhyo's explanation is very similar to Fazang's in the Huayan wujiao zhang. Both of them consider the Jiujing yisheng baoxing lun one foundation.

In addition, concerning the relationship between zhongxing and practice stages, Wŏnhyo stated the below in the Kisillon so (Chin. Qixin lun shu) 起信 論疏 [Commentary on the Dasheng qixin lun]:

Practitioners have to practice the samädhi of zhenru if they want to enter the stage of zhongxing that will not fall behind. There is completely no other way whereby one can enter the stage of zhongxing that will not fall behind. It is therefore said that this is the only way to that boundary. On the other hand, there are two gates at the stage of zhongxing. The first one is the gate of thirteen remains. Namely, the initial stage is zhongxing zhu zhongxing 種性住種性 (instinctive gotra). This kind of zhongxing existed from the beginning, and could not be obtained by any kind of practice. This has been stated by the Yuqieshi di lun and the Pusa dichi jing. The second one is the gate to the six kinds of zhongxing. Namely, the initial stage is $x i$ zhongxing. The stage after that is xing zhongxing. This is located at the three wisdoms and consists of habit. This meaning has been stated by the Pusa yingluo benye jing and the Renwang jing. The details of these two manuscripts have been described in the Yidao yi一道義 [Explanation on One Path]. The rulai zhongxing 如來種性 (the caste of rulai) means the second gate. 行者要修真如三昧、方入種性不退位中。除此更無能入之道、 故言不習無有是處。然種性之位有其二門。一、十三住門。初種性住種性者、 無始來有、非修所得。義出《瑜伽》及《地持論》。二、六種性門。初習種性、

${ }^{34}$ Beophwa jong-yo, $T$ no.1725, 34: 875a20-875b17. 
次性種性者、位在三賢、因習所成。出《本業經》及《仁王經》。於中委悉、如 《一道義》中廣說也。今此中言如來種性者、說第二門習種性位也。35

That is to say, the instinct zhongxing that is stated by the Yuqieshi di lun and the Pusa dichijing is instinctive and cannot be attained through practice. This is obviously different from the zhongxing stated by the Pusa yingluo benye jing and the Renwang jing. On the contrary, the instinct zhongxing which is stated by the Pusa yingluo benye jing and the Renwang jing is located after the habit zhongxing. Both of this two kinds of zhongxing can be attained through practice. Moreover, Wŏnhyo utilizes the theory of zhongxing in the Pusa yingluo benye jing and the Renwang jing to explain the "zhongxing of rulai".' Clearly, as for Wŏnhyo, the theory of zhongxing in the Pusa yingluo benye jing and the Renwang jing is more significant than that of the Yuqieshi di lun. We can recognize easily that the theory of zhongxing in Fazang's Huayan wujiao zhang was influenced by Wŏnhyo. Both of them primarily utilized the theory of zhongxing in the Pusa yingluo benye jing and the Renwang jing as their foundation.

\section{Conclusion}

I have examined quotations and interpretations of the Jiujing yisheng baoxing lun and the Pusa dichi jing which were utilized by Fazang when he explained his theories of zhenru 真如 (Skt. tathatā) and zhongxing 種姓 (Skt. gotra). In conclusion, we can say that Fazang greatly valued the Jiujing yisheng baoxing lun and the Pusa dichi jing. These two scriptures played a very significant role in Fazang's theory of zhenru, especially his theory of Huayan xingqi. Similarly, Fazang's theory of zhongxing used the Jiujing yisheng baoxing lun and the Pusa dichi jing as its foundation. Clearly, the Jiujing yisheng baoxing lun is one of the most important scriptures for understanding Fazang's thought. As is widely known, Fazang is one of the most significant figures when discussing the origin and history of rulai zang yuanqi and zhenru yuanqi in Chinese Buddhist history. Therefore, Fazang's quotations and explanations of the Jiujing yisheng baoxing lun are a necessary step towards the resolution of this difficult problem.

\section{Bibliography}

$\mathrm{T}=$ Taishō shinshū daizōkyō. Takakusu Junjirō 高楠順次郎 and Watanabe Kaigyoku 渡 邊海旭 eds. Taishō shinshū daizōkyō 大正新修大蔵経 [Buddhist Canon Compiled

${ }^{35}$ Kisillon so, $T$ no.1844, 44: 2.224b18-224b26. 
under the Taishō Era (1912-1926)]. 100 vols. Tokyo: Taishō issaikyō kankōkai 大正一切 経刊行会, 1924-1932.

\section{Primary Sources}

Beophwa jong-yo (Chin. Fahua zongyao) 法華宗要 [Doctrinal Essentials of the Lotus Sutra], 1 gwon, by Wŏnhyo 元曉 (617-686), $T$ no. 1725 vol. 34.

Dasheng fajie wuchabie lun shu 大乘法界無差別論疏 [The Sub-commentary on the Treatise on Non-Distinction in the Great Vehicle Dharma Realm], 1 juan, by Fazang 法藏 (643-712), $T$ no. 1838, vol. 44.

Huayan jing neizhangmen deng za kongmu zhang 華嚴經内章門等雜孔目章 [An Essay on the Outline of Huayan], 4 juan, Zhiyan 智儼 (602-668), T no.1870, vol. 45.

Huayan jing tanxuan ji 華嚴經探玄記 [Record of the Search for the Profundities of the Huayan Sutra], 20 juan, by Fazang 法藏 (643-712), T no. 1733, vol. 35.

Huayan yisheng jiaoyi fenqi zhang 華嚴一乘教義分斉章 [The Chapter on One Vehicle Teaching of Huayan], 4 juan, by Fazang 法藏 (643-712), T no. 1866, vol. 45.

Jiujing yisheng baoxing lun 究竟一乘寶性論 [Treatise of the Jewel-nature of Ultimate One], 4 juan, Trans. Ratnamati 勒那摩提 (477?-569?), T no. 1611, vol. 31.

Kisillon so (Chin. Qixin lun shu) 起信論疏 [Commentary of the Awakening of Faith in the Mahayāna], 2 gwon, by Wŏnhyo 元曉 (617-686), T no. 1844, vol. 44.

Pusa yingluo benye jing 菩薩瓔珞本業經 [Sutra of the Diadem of the Primary Activities of the Bodhisattvas], 2 juan, allegedly translated by Zhu Fonian 竺佛念 (of the $4^{\text {th }}$ c.). $T$ no. 1485 , vol. 24 .

\section{Modern Studies}

Chen, Jinhua. Philosopher, Practitioner, Politician: The Many Lives of Fazang (643-712). Leiden: Brill, 2007.

Forte, Antonino (ed.). Tang China and Beyond: Studies on East Asia from the Seventh to the Tenth Century, Kyôto: Italian School of East Asian Studies (Essays, vol. 1), 1988.

. A Jewel in Indra's Net: The Letter Sent by Fazang in China to Uisang in Korea. Kyôto: Italian School of East Asian Studies, 2000.

Ishii Kōsei 石井公成. 'Daitōa kyōeiken no gōrika to Kegon tetsugaku: Kihira Tadayoshi no yakuwari wo chūshin nishite’ 大東亜共栄圈の合理化と華厳哲 
学（一）一紀平正美の役割を中心にして’ [The relationship between the East Asian and Huayan Philosophy: With a focus of the function of Kihira Tadayoshi]. Bukkyōgaku 佛教学 [Buddhist Studies] 42 (2000): 1-28.

Johnston, E. H. (ed.). Ratnagotravibhāga Mahanottaratantraśāstra. Patna: The Bihar Research Society, 1950.

Kamada Shigeo 鎌田茂雄. Chūgoku Kegon shisōshi no kenkyū 中国華㛜思想史の研 究 [Study on the history of Chinese Huayan thought]. Tokyo: Tōkyō daigaku shuppankai 東京大学出版会, 1965.

Kim Songchol 金成哲. 'Shushō mui ron no kigen ni kansuru ichikōsatsu: Hōshōron to Busshōron no Gotra no honyaku yōrei wochūshin toshite’ 種姓無為論の起源 に関する一考察—《宝性論》と《仏性論》の'gotra'の翻訳用例を中心と $\iota \tau$ [A study on the origin of the theory of unconditional gotra: with a focus on the translation of gotra in the Ratnagotravibhāga and the Foxing lun (Treatise on Buddha Nature)]. In Higashiajia bukkyō gakujyutsu ronshū 東アジ ア佛教学術論集 [Journal of East Asian Buddhist Studies], Vol. 2. Tokyo: Tōyō daigaku tōyōgaku kenkyūjo 東洋大学東洋学研究所, 2014, pp. 235-258.

Kimura Kiyotaka 木村清孝. Shoki chūgoku kegon shisō no kenkyū 初期中国華峳思想 の研究 [Study on the early history of Chinese Huayan thought]. Tokyo: Shunjūsha 春秋社, 1977.

Kobayashi Jitsugen 小林実玄. ‘Kegon Hōzō no jiden nitsuite’ 華厳法蔵の事伝につい て [On the biography of Fazang]. Nanto bukkyō 南都佛教 [Southern Capital Buddhism] 36 (1976): 25-53.

Li Zijie 李子捷. '7 seiki izen no Chūgoku Bukkyō no shushōsetsu nitsuite: Bosatsu jiji kyō Ninnō kyō Yōraku hongō kyō wo chūshin ni’ 7 世紀以前の中国仏教の種 姓(性)説について一《菩薩地持経》・《仁王経》・《瓔珞本業経》を中心に $[$ The theory of gotra in Chinese Buddhism before the $7^{\text {th }}$ century: With a focus on the Pusa dichi jing (Sūtra of Bodhisattva Stages), Renwang jing (Sūtra of Benevolent King) and Yingluo benye jing (Sutra of the Diadem of the Primary Activities of the Bodhisattvas)]. Indogaku bukkyōugaku kenkyū 印度学佛教学研究 [The Japanese Association of Indian and Buddhist Studies] 65-1 (2016): 185-189. . 'Daijō kishin ron no shinnyosetsu no ichikōsatsu: Kukyō ichijō hōshō ron no nyoraizō setsu to no kankei wo chūshin toshite’ 《大乘起信論》の真如説の 一考察—《究竟一乗宝性論》の如来蔵説との関係を中心として [The theory of tathatā found in the Dasheng qixin lun (Awakening of Faith in the Mahayāna): With a focus on the relationship with the Ratnagotravibhāga]. Higashiajia Bukkyō gakujyutsu ronsh ū 東アジア佛教学術論集 [Journal of East Asian Buddhist Studies] 4 (2016): 225-245.

. 'Kukyō ichijō hōshō ron no shinnyosetsu no ichi kōsatsu: Higashiajia Bukkyō niokeru shinnyo rikai to no kanren wo chūshin ni'《究竟一乗宝性論》 の真如説の一考察一東アジア仏教における真如理解との関連を中心に [A study on the theory of tathatā in the Ratnagotravibhāga: With a focus on the 
relationship with the understanding on tathatā in the East Asian Buddhism]. Bukkyōgaku 佛教学 [Buddhist Studies] 57 (2016): 37-62.

. 'Nanbokuchō Zui-Tō Bukkyō to Bosatsu jiji kyō' 南北朝隋唐仏教と《菩 薩地持経》 [The Buddhism in Northern and Southern dynasties and the Pusa dichi jing (Sūtra of Stages of Bodhisattvas)], Komazawa daigaku bukkyō gakubu ronshu 駒澤大学佛教学部論集 [Journal of Buddhist Studies at Komazawa University] 48 (2017): 289-310.

Matsumoto Shirō 松本史朗. Bukkyō shisō ron shita 佛教思想論 - 下 [Study on the Buddhist Thought, Volume 2]. Tokyo: Daizō shuppan 大蔵出版, 2013.

Nakajō Dōshō 中條道昭. 'Chigon no kyōhan nitsuite' 智儼の教判について [The Doctrinal Classification of Zhiyan]. Komazawa daigaku bukkyō gakubu ronshu 駒澤大学佛教学部論集 [Journal of Buddhist Studies at Komazawa University] 9 (1978): 612-613.

Ōtake Susumu 大竹晋. 'Shōron gakusha Chigon' 摂論学者 智儼 [Zhiyan as a Shelun School's monk]. Tetsugaku shisou ronso 哲学 ・思想論叢 [Series of Philosophy and Thought] 18 (2000): 49-60.

Takamine Ryōshū 高峯了州. Kegon kumoku shō kaisetsu 華㛜孔目章解説 [The Interpretation of the Huayan kongmu zhang (Essay of the outline of Huayan)]. Nara: Nanto bukkyō kenkyūkai 南都佛教研究会, 1964.

Kegon shisosshi 華㛜思想史 [The history of Huayan thought]. Kyoto: Hyakaen 百華苑, 1976.

Takasaki Jikidō 高崎直道. Hōshō ron 宝性論 [Treatise of the Jewel-nature of Ultimate One]. Tokyo: Kōdan sha 講談社,1989.

Tokiwa Daijyō 常盤大定. 'Zui no Reiyū to Sangaikyō no Nanakai Butsumei' 隋の霊 裕亡三階教の七階佛名 [Lingyu in Sui Dynasty and Buddha names of seven stages]. In Shina bukkyō no kenkyū Daiichi 支那佛教の研究・第一 [Study on Chinese Buddhism, the first volume], edited by Tokiwa Daijyō 常盤大定. Tokyo: Shunjūsha 春秋社, 1938.

Yoshizu Yoshihide 吉津宜英. 'Hōzō daijō kishin ron giki no kenkyū' 法蔵《大乗起信 論義記》の研究 [A Study on Fazang's Dasheng qixin lun yiji (Commentary on the Awakening of Faith in the Mahayāna)]. Komazawa daigaku bukkyō gakubu ronsh $\bar{u}$ 駒澤大学佛教学部論集 [Journal of Buddhist Studies at Komazawa University] 11 (1980): 139-156.

. 'Hōzōden no sai kentō' 法蔵伝の再検討 [Re-investigation on Fazang's biography]. Shūkyō kenkyū 宗教研究 [Study on Religion] 5-23 (1979): 168193.

. 'Kegon gokyō shō no kenkyū' 華稂五教章の研究 [Study on the Huayan wujiao zhang (Treatise on five kinds of teaching on Huayan)]. Komazawa daigaku bukkyō gakubu kenkyū kiyo 駒澤大学佛教学部研究紀要 [Journal of the Faculty of Buddhist Studies, Komazawa University] 36 (1978): 169-191. 
Yutsugi Ryōei 湯次了栄. Kegongokyōshō kōgi 華厳五教章講義 [A lecture on the Huayan wujiao zhang (Treatise on five kinds of teaching on Huayan)]. Kyoto: Hyakaen 百華苑, 1927.

\section{Zijie 李 子捷 (SOAS University of London)}

Li Zijie, Phd Of Komazawa University In Tokyo. He Was Under The Guidance Of Professor Ishii Kosei And Professor Matumoto Shiro, Postdoctoral Researcher At The Institute Of Humanities,Kyoto University And Studied Under The Guidance Of Professor Toru Funayama. He Is Now A Postdoctoral Fellow At SOAS University Of London And Is Studying Under The Guidance Of Professor Lucia Dolce. His Main Research Area Is The History Of East Asian Buddhism In The 5-7 Century. 